\title{
A COMPARATIVE ANALYSIS OF THE EU INTEGRATION PROCESS OF ALBANIA AND KOSOVO
}

\section{KOMPARATIVNA ANALIZA EU INTEGRACIJSKOG PROCESA ALBANIJE I KOSOVA}

\author{
Zerina Čaušević \\ zerina.causevic@ibu.edu.ba
}

\begin{abstract}
Having their populations add up to over $80 \%$ of Albanian ethnicity, Kosovo and Albania can be conceptualized as being closely intertwined namely when it comes to their foreign policies. This article will primarily focus on the foreign policies of Albania and Kosovo through the lens of their major foreign policy goals and their connections with the European Union. The path of the contemporary existence of Albania and Kosovo has been marked by various events such as the dissolution of Kosovo from Serbia. Their primary efforts include building and maintaining a democratic society that would enable the two countries to gradually flourish and establish closer ties with neighboring countries as well as Europe and the EU if successful. This research provides a comparison of the two foreign policies through a lateral method by also focusing on one of the three levels of analysis, the individual, state, and system. Within the individual level emphasis is laid on crucial individuals such as Rama, Pacolli, Cakaj, and Meta. This level of analysis and the outline of influential decisionmakers statements and actions can confirm the idea that the two countries of Kosovo and Albania can survive only in case of successful cooperation amongst each other as well as through Euro Atlantic integration namely with the European Union.
\end{abstract}

Sažetak: Sa $80 \%$ populacije albanske nacionalnosti, Kosovo i Albanija mogu biti koncipirani kao blisko povezani kada su u pitanju njihove vanjske politike. Primarni fokus članka je na vanjskim politikama Albanije i Kosova kroz prizmu njihovih glavnih vanjskopolitičkih ciljeva $i$ veza sa Evropskom unijom. Put savremene Albanije $i$ Kosova je obilježen raznim događajama, kao što je rastvaranje Kosova od Srbije. Primarno napori uključuju izgradnju i održavanje demokratskog društva koji bi osigurali da dvije države dožive procvat i uspostave bliže odnose sa susjednim državama, kao $i$ Evropom i EU ako budu uspješni. Ovo istraživanje je komparacija dvije vanjske politike lateralnom metodom kroz

Keywords: Albania, Kosovo, EU, Foreign Policy,

Integration

JEL Classification: $F 50$

Article History

Submitted:30/12/2021

Accepted:31/12/2021

Ključne riječi: Albanija, Kosovo, EU, vanjska politika, integracija

Historija članka

Dostavljen: 30.12 .2021

Prihvaćen: 31.12.2021 
fokusiranje na tri nove analize: individualni, državni $i$ sistemski. Unutar individualnog nivoa, naglasak je dat pojedincima kao što su Rama, Pacoli, Cakaj i Meta. Ovaj nivo analize i pregled govora $i$ djela utjecajnih donosioca odluka na Kosovu i u Albaniji dokazuju da dvije države mogu jedino opstati kroz uspješnu saradnju međusobno te kroz euroatlantske integracije, naročito sa EU. 


\section{INTRODUCTION}

Throughout the history of states and international affairs, influential events leading countries to disastrous conditions or very prosperous conditions of the state have taken place. Hence, the foreign policies of states are to be considered as being one of the most crucial impacting factors in the success of a state in the international sphere. The foreign policy also known as the foreign relations of a certain country is most broadly defined as the approaches molded to achieve the desired goals of the country pursuing them. Hence the study of foreign policy analysis can be described as being "actor-specific" in a sense that it focuses on the foreign policy of a certain actor and aspects including the actions, results, effects, and impacts within the foreign policy decision making of the country. This analysis study is in most cases conducted with having a certain case or country in focus or a comparative method as this research is done. The entire significance of the foreign affairs or foreign policy sector of a country lies beneath the fact that during the current period no state or organization, governmental or nongovernmental can survive without inclusion in the international relations arena.

Such interactions ought to be generated and functioning according to a certain set of frameworks that are, on the foreign policy it has created and molded to suit its needs and fulfill its goals. It is widely spread common knowledge that the major impact of the course and foci of a country's foreign policy revolves generally around its domestic politics and internal condition of the country. Despite the seemingly "well organized" foreign policy sectors of countries, events of powerful impacts have occurred in different periods. Characterized as some of the most significant and most widespread influencing factors of the abovementioned events have been demographics and ethnic structures.

Moreover, the fact that some states have ethnicities of differentiating characteristics residing within their territories has majorly been the trigger for conflicts, both armed and unarmed. Countries characterized as such are Albania and Kosovo. The two countries have had demographics play a major impact on their foreign policies towards third political entities including different organizations and eventually resulted in their unenviable situations taking place contemporarily. For example, the demographic statistics display Albania as a homogeneous country having more than 97\% Albanian majority of the total population of nearly 3,000,000. ("Europe: Albania-The World Factbook-Central Intelligence Agency",2020). Whereas when viewing the religious aspect 57\% of the population are Muslim, 10\% Roman Catholic, and 6.8\% orthodox. ("Europe: Albania-The World Factbook-Central Intelligence Agency",2020). On the side, there is Kosovo is home to $92 \%$ of Albanians of their total population of 1,932,000 people. ("Europe: Kosovo The World Factbook - Central Intelligence Agency", 2020) The religious groupings of Kosovo count 96\% Muslim, 2\% Roman Catholic, and 1.5\% orthodox. ("Europe: Albania-The World Factbook-Central Intelligence Agency",2020)

This eventually led to the two countries having similar structures of their foreign policy and relations with organizations such as the European Union. Albania was one of the first countries to recognize the independence of Kosovo once it has separated from Serbia. One of the major impacts has been their similar interests. Consequently, the question of how similar or how not similar are the foreign policies of the two states and how differentiated is their position within the study of international relations will be one of the topics of this research. 
This topic is significant because an absence of comparative research regarding Albania and Kosovo has been identified. Primarily, this lack infers to the topic of the foreign policies of Albania and Kosovo followed by their comparison and their position regarding Euro Atlantic integration and the European Union. The scholarly literature available on the topic of the foreign policies of Albania and Kosovo is not as numerous and extensive as it may be with some other states. A majority of the literature available is most generally focused and based on the periods from the dissolution of Kosovo from Serbia, its ethnic divisions by providing a historical context to some of the current affairs it has been facing. Moreover, the literature available on this topic also partially mentions and elaborates on the roles Albania and Kosovo have in a sense as to what processes or actions have been taken towards their membership in certain international organizations. The research gap acknowledged in this research has been identified as being extensive through data collection methods such as desk research, content analysis, and archival analysis. One of the major causes which have eventually led to the formation of this literature gap has been the conventional views of the issues taking place in Albania and Kosovo. The major issues within research on the topic of Albania have been topics such as religion, ethnicity, development, and in the recent period tourism. Whereas the Republic of Kosovo has had a majority of the works on the topic of its secession from Serbia coupled with the process of nation-building and the formation of a stable government.

This article begins with brief elaborations of the countries of Albania and Kosovo and their relations with the EU. Moreover, it will focus on one of the three levels of analysis, the individual, state, and system-level of analysis. Namely, it will emphasize the individual level of analysis. This level of analysis will focus on considerable issues about the two countries' foreign policies. These shall include their integration into the European Union, the independence of Kosovo as well as their recognition within world affairs. Furthermore, when it comes to the above-mentioned discussion on the individual level, it will focus on the choices and actions of impactful decisionmakers. Lastly, it will conclude with remarks and highlights of the major possible differences, similarities, and impacts of Albania and Kosovo's foreign policy. The relevance of this topic lies beneath the fact that the study of foreign policy as well as the comparison of foreign policies and their results, outcomes, and impacts can influence future issues within this field of study.

\section{ALBANIA AND THE EUROPEAN UNION}

During the research on the major foreign policy missions of Albania and its Ministry of Foreign Affairs, the EU membership, as well as the strengthening of the regional security, economic development,and political stability, are all primary foreign policy priorities. The NATO membership taking place in 2009 is also of significance since in the understanding and interpretation of the authorities of Albania they are deeply interconnected. To begin with, it must be highlighted that Albania holds for a country having had the longest negotiations until the act of signing the Stabilization and Association Agreement. Furthermore, corruption taking place within its government, poor compromises, and a general lack of direction regarding how to bring the state to where it is had hindered this difficult process.

What is more, Albania has also encouraged its citizens living in the countries of the region and elsewhere to be supporters of the EU and the Euro-Atlantic integration processes and the principles 
that they involve. In addition to that is them being very loyal to the world, the Union, and NATO in their foreign policy practices. Moreover, Euro-Atlanticism, a central aspect of Albania's foreign policy is support for Kosovo's independence. At the 2003 EU-Western Balkans Summit in Thessaloniki, Albania obtained a rank as a possible candidate for membership. (Dzananovic, 2020) Along with that is the Stabilization and Association Agreement with the EU which entered into force in 2009 and in April submitted a formal application to join. It has had the status of a Member Candidate since June 2014. Regarding the judiciary, the fight against corruption and organized crime, and the reform of intelligence and the civil service, there was no call to align Albania's foreign policy with the EU CFSP. As a result, through its annual reports, the European Commission has repeatedly highlighted Albania's strong preparation for inclusion in the EU's international, security and defense policy, for which related ministries have been commended.

The degree of enforcement has been utterly remarkable over the years. Albania has managed in adopting the traditional positions of the EU easily whenever invited. It has also easily entered any restrictive measures taken by the European Council. About this statement, a disputable question of how capable Albania is due to facts such as it having an underdeveloped government. The High Representative for Foreign Affairs and Security Policy has fully backed all Council resolutions and declarations. Furthermore, Albania has through work with the EU through NATO, supplied surplus arms to Kurdish forces fighting Da'esh, participated in the ALTHEA ${ }^{1}$ military mission in $\mathrm{BiH}$, and the training mission in Mali (EUTM), which would have been impossible without the EU background. It also declared its willingness to participate in $2024 \mathrm{EU}$ battle groups. (European Commission, 2020)

Significant EU and Euro-Atlantic contributions were also articulated by cooperation with other international organizations and initiatives, in which Albania played a constructive role-OSCE (Organization for Security and Co-operation in Europe), SEECP (South East European cooperation process), AII (Adriatic and Ionian initiative), CEI (Central European Initiative), Berlin Process, Brdo-Brijuni Process, and WB6. (Dzananovic, 2020) Tirana has also been RYCO headquarters and the Western Balkans Trust. Responding to current concerns such as migration (Regional Initiative for Migration and Asylum) and the fight against terrorism and radicalism (Western Balkans Anti-Terrorism Initiative) has shown a high degree of timeliness and usefulness. On the contrary, Albania does have certain requests to which it reacts negatively, does not agree to, and which uncovers the notion that Albania possesses a particularly significant bilateral relation which it intends to keep out and away from the context of the EU. It is the relationship with the United States of America. Explaining this is the mutual immunity agreement with the United States in 2003, which exempts American citizens from the International Criminal Court. This is in contrast with the views of the EU.

\section{KOSOVO AND THE EUROPEAN UNION}

Next, there is Kosovo which has not been yet proclaimed as independent by all countries. It is known to be the youngest country of the Balkan region whilst having international recognition of

\footnotetext{
${ }^{1}$ The military operation ALTHEA in Bosnia and Herzegovina (BiH) was launched on 2 December 2004 and has contributed to the maintenance of the safe and secure environment in $\mathrm{BiH}$ ever since
} 
114 countries. However, several countries including Pacific and African countries have withdrawn their recognition following the diplomacy campaign of Serbia. (Dznanovic, 2020) This implies that the exact number is yet unknown and disputable. Fortunately, Kosovo has achieved its diplomatic goal stating that it aims to have international recognition of more than 100 countries. Significant to point out is that its independence has not been recognized by countries such as Spain, Slovakia, Greece, Cyprus, India, and Romania. Before touching up upon the EU and Kosovo, it must be highlighted that the major cause for four out of five of the countries not recognizing Kosovo is the ties with Serbia. Once Serbia recognizes Kosovo, consequently, eventual recognition in the future is possible. Yet, for example, Spain emphasized that its refusal to acknowledge had little to do with Serbia's views, but with the fact that the unilaterally proclaimed independence does not adhere to the accepted international standards, which is a stance formed by internal reasons. However, Spain has clear objections to Kosovo's case in the sense of enlargement, and to the very term WB6, as this is prejudicing its statehood.

Consequently, this reality has not only split the EU and kept Kosovo from being recognized as a whole, but it has also set some important precedents in the treatment procedure. Starting with the name itself, Kosovo is Kosovo for the EU, with a * character pointing to a footnote saying that "the appointment does not prejudge either the position or the status, but the treatment by UNSCR 1244 and the ICJ Opinion on the Declaration of Independence of Kosovo". (International Court of Justice, 2010) Furthermore, according to WB6, the EU, and its officials in Sofia, the word "partners" started to be used rather than "states" to avoid indirectly announcing Kosovo's status. Likewise, when it comes to the region, Serbia and Bosnia and Herzegovina do not recognize the independence of Kosovo as well. In special guidance, the European Union has explained that the signing of the Agreement does not mean that the EU recognizes Kosovo. Consequently, the EU is that it is a Stabilization and Association Agreement (SAA) signatory and a possible candidate for membership. Coupled with that, the EULEX as mentioned previously is the largest civilian operation ever under the auspices of the CSDP in Kosovo.

On top of that, the people of Kosovo are the only ones in the region who are still subject to the visa regime with the Schengen Agreement members. However, the European Commission has reported that Kosovo fulfilled the requirements for visa liberalization and recommended that the visa regime be abolished by July 2018. (Dzananovic, 2020) Kosovo has also adopted the use of the euro as its currency unilaterally, as has Germany, and the question of the use of the currency will be addressed during future accession talks.

Effective neighborly relations and regional cooperation form part of the process of Kosovo integrating into the European Union as well as its foreign policy priorities. The basic prerequisite and a special part of the Annual Progress Report relates to the relations with Serbia and the process of regulating the relations in addition to an EU-led political dialogue. Effective governance, rule of law, growth, and investment, jobs, and education are the priorities of the European Commission in Kosovo according to the Reform Agenda. As with other signatories of the SAA, activities are specially monitored in the regional context, which contributes to an environment of positive and productive relations.

Next, Kosovo does participate in the work and membership of several national organizations and initiatives including the CEFTA, SEECP, MAARI (migration, asylum, refugees' regional initiative), RCC (regional cooperation council), Energy Group, RECOM (regional commission for 
the establishment of facts about war crimes), Brdo-Brijuni, under an agreement reached with Belgrade and under the auspices of the European Union in 2012. (EWB, 2021) It is also involved in implementing the Multilateral Action Plan (MAP) for REA (Regional Economic Area) growth. This implies that it has been productive to preside over regional events and activities. In addition, Kosovo took over the SEECP and MAARI presidencies in 2019 and chairs the board of directors of RYCO. It also forms part of the agenda of the Berlin Process, ZB6 and Connectivity, and RESPA (Regional School of Public Administration). Ties and relations with the country of Serbia and the duty to normalize relations with Serbia is Kosovo's most critical and dynamic task, in which the EU has been engaged intensively since 2012 .

\section{THE INDIVIDUAL LEVEL OF ANALYSIS}

When elaborating on some of the most significant issues regarding Albania and Kosovo, it can be stated that these include their accession to the EU and the independence of Kosovo. The individual level of analysis predominantly emphasizes decision-makers and leaders with an attempt to describe foreign policy. This analysis of individual characters has the potential to either emphasize their perceptions, their personalities, or how they comprehend their world and events taking place. Furthermore, they frame the path of history because their decisions, thoughts, and choices determine the path of various events.

Specified as having similar or in certain cases equal aims and objectives regarding their foreign policies as well as domestic, an agreement on the unification and coordination of their foreign policies has been signed by Albania and Kosovo in 2019. This includes joint embassies also. This has been made public by the foreign minister of Kosovo Behgjet Pacolli on his Twitter profile. Stated has been that "this is a big step forward in our national integration and to perform together before the world" in the wake of signing the agreement with the Albanian colleague Ghent Cakaj. The sense of unity and unified ambitions has assisted both of the countries during difficult events such as the ongoing process of joining the EU. When it comes to further discuss and elaborating on the individual level of analysis, Behgjet Pacolli is considered relatively to be a newcomer to politics. On the other hand, he has been revolving around newspaper investigations, European business surroundings as well as Russian, Switzerland, and Kazakhstan newspaper titles. ("About Behgjet Pacolli: Swiss businessman", n.d.) Pacolli is approximately a complex character, as is expected of an individual of such biography. Being a former president of Kosovo, elected in 2011,("Balkan Focus Just who is Behgjet Pacolli?", 2011) Pacolli is part nationalist, part modernist. Along with that he is viewed as being part introspective, part western looking, part effortless politician, and part businessman. $€ 420 \mathrm{~m}$ which equals over ten percent of the total GDP of Kosovo is his estimated personal wealth level. ("Balkan Focus Just who is Behgjet Pacolli?", 2011) Despite being a committed nationalist of Kosovo his life has been based in Switzerland for the past 3 to 4 decades. Beghjet Pacolli is known to be the owner of media organizations, construction businesses, and other companies throughout the continent of Europe.

Taking a deeper insight into his personality, the nature of Pacolli revolves around his humble beginnings and his wealth. Coupled along with that is his persona cautiously crafted by being an entirely self-made man. In other words, he is someone who has achieved to result at the top without having anything handed or supplied to him. Pacolli is at the minimum an intriguing figure to serve the function of leading this intriguing country. The reality, however, is more nuanced and worth 
investigating; while its history was certainly modest, the mysterious elements of its past including its ties to suspected corruption in Russia - point to a transformation predicated more on greased hands than raised welfare queens.

While referring to the other side of the agreement, Cakaj states the following" close coordination of the two countries, creation of joint diplomatic missions and exchange of staff and experience have been agreed, all to apply national interests". ("Kosovo I Albanija potpisali sporazum o ujedinjenju vanjske politike", 2019)This agreement has the ability to open newly crafted horizons and possibilities for joint institutional action as the two countries of Kosovo and Albania approach even deeper national integration. However, despite the aims, it can be also said that this might not bring along significant benefits in practice. Supporting opinions of this thought state that "it is more like a patriotic show than a concrete political action to improve relations" ("Kosovo I Albanija potpisali sporazum o ujedinjenju vanjske politike", 2019) as stated by Professor Ezio Kraki, at the University of Paris-Est Creteil. The foreign policy of Albania is not comprehended as being in line with that of Kosovo and for now, it is enough for one country to avoid or to not be an obstacle to the other country.

Furthermore, when discussing the country of Albania and its president Ilir Meta, it is necessary to highlight some of the most significant details regarding his biography. Ilir Meta has been serving the function of the president of Albania since $24^{\text {th }}$ July 2017. ("About Ilir Meta: Albanian diplomat and politician (1969-)", n.d.)Meta held the function of prime minister from 1999 to 2002 and the function of Foreign Minister from 2002 to 2003 and from 2009 to 2010. ("About Ilir Meta: Albanian diplomat and politician (1969-)", n.d.) Later on, he held the position of the Speaker of the Albanian Parliament. Since 1990, he also held the positions of Deputy prime Minister and Minister of Economy. Consequently, it can be pointed out that Ilir Meta has been actively participating in the student's movement against communism which in turn brought along democratic pluralism to Albania. When focusing on an individual level of analysis it proves to be of significance to mention the origins of the certain influential individual's aspirations and goals. Ilir Meta in this instance succeeded Pandeli Majko's position as the Prime Minister for the Socialist Party of Albania back in 1999. ("About Ilir Meta: Albanian diplomat and politician (1969-)", n.d.) Following his second election, he endured within this position until 2002. This period can be characterized as having Albania involved in significant reforms due to the aspirations of Ilir Meta. These include the joining of the Stabilization and Association Process with the European Union. Moreover, Meta initiated and established his own Socialist Movement for Integration (LSI) consequently after leaving the Socialist Party. The establishment of such a party lays partially lays out elaborations for the future actions, goals, and priorities emphasized by Albanian President Ilir Meta.

Lastly, in the process of discussing this individual and before pointing out some of his outlooks and actions it should be stated that Meta has gained the "Most Positive Personality for 2010 in foreign Policy" Award in 2012 by the International Institute IFIMES in Ljubljana. This award has the President of IFRAMES. The major highlights of his career resulting in him being the most positive political personality and with this award include his precise contribution in the process of operating the foreign policy of his country Albania. In addition to that is his institutional and personal impact in the firming of good neighborly and regional cooperation among the Western 
Balkan countries. Meta's vision has been honored and admired by the IFRAMES at the crown of Albanian diplomacy.

Meta has been viewed as owning a political personality characterized by having regional weight as well as having a vivid purpose in establishing a more integrated, open, and positive region. (Kurani, 2018) Having the above pointed out and referring to the individual level of analysis, Albania is to be marked as a country having individuals capable of succeeding in the EU joining process, whereas on the other hand, the differentiated targets provide a hinder. Notable in the life of Ilir Meta is his active inclusion in various legislative committees. Furthermore, the central focus of his term includes the European integration process and the challenges impacting Albania in the global sphere. The willingness of Albanians in firming the bilateral strategic partnerships and cooperation with a majority of its partnering countries in the region has been accentuated. Along with this is the area of security and NATO.

Accordingly, concerning the president of Albania, Ilir Meta, and elaborating on Albania and some of its aspects of foreign policy with a revolve around the EU, Ilir Meta wants Albanians to topple the socialist government of their country. He states that this government has "grabbed every independent institution" and become a "one-party regime". Its president has recently warned Albania has the risk of transforming into the "North Korea of Europe". This came because of him defending his role following a constitutional struggle threatening to challenge and hinder the path of Albania towards its accession to the EU. Furthermore, this has been proved by Meta stating in an interview with good morning Europe that changes and amendments to the constitution might pull Albania back 30 years. He said "Albania could return to its Cold War status as "the North Korea of Europe"'.(Jamieson, Sanford, 2020)_Meta believes he is fighting a "battle for democracy" and insists it isn't a power tussle with Prime Minister, Edi Rama.

Likewise, what is represented in Albania is a political struggle in which the president, who is supposed to be above party politics, is irritated by the domination of the left-wing socialist party, and thinks there is a significant hold on power. He wants to contest that but thinks that the political means to do so are not going anywhere. This is viewed by the state as a misunderstanding. It assumes that the President goes well beyond his control. He is meant by a unifying leader who is above politics; that's not the case anymore, which is why Rama suggests that shortly there will be a push to impeach the president. Here it is evident that the individuals of significance to the foreign policy of Albania and its goal of EU enlargement are in certain scenarios like the one above in collision. (Jamieson, Sanford, 2020) Moreover, a personality clash between two of Albania's leading politicians has been going on for decades and it is easy to see why the country has ended up in a mess that has profound and intense consequences. About that, there was quite a bit of upset at the end of 2019 when France and the Netherlands essentially vetoed Albania and North Macedonia's attempts to join the EU. (Jamieson, Sanford, 2020) A concerted effort will be made to try to restart the cycle at a special Balkan summit. Given that the judiciary is active in this crisis in Albania, it can be said that Brussels will look closely and that this conflict will result in consequences for the European ambitions of Albania.

The conflicting characters of Ilir Meta and Edi Rama as holding two of the most significant positions regarding the foreign policy and overall government of Albania has undoubtedly prevented the country from achieving. Once looking at Edi Rama as an individual, it can be pointed out that his Revival agenda was focused on four pillars: the democratization of state institutions, 
European integration, restoration of public order, and economic revitalization. As of September 15, 2013, Rama has served as Albania's 33rd Prime Minister. Throughout the election campaign, Rama claimed his number one goal was the restoration of public order within his country. In 2013, it was managed to have just 55 percent of the region to be fully guarded by the Albanian police. This fact proves that the government has extensively invested in the modernization, recruitment, and enhancement of the police force's financial benefits. An attention-grabbing detail would be that Edi Rama has been the first Albanian politician having visited Belgrade since 1948. (Domi, n.d) During such a meeting one of his major stances was the recognition of Kosovo and the point that it is a reality all must eventually accept.

As on the matter of the EU Rama has claimed on many occasions that the European Union needs to speed up the Western Balkans integration process, finding it the only way to overcome the region's dangerous divisions. Furthermore, it has the potential of avoiding an outbreak of conflicts, such as the ones taking place in the area in the 1990s. ("PM Edi Rama: Albania is Europe's bleeding organ", 2019) What is more, Rama has criticized the growing Russian presence in the region as being destabilizing. On the other hand, facing potential and increasing contradictions with his proEuropean enlargement stance, he improved ties with Turkey, namely Erdogan's Administration. Strongly accentuated is the fact that the main national goal of Albania is that of joining the European Union. However, Prime Minister Edi Rama does not believe that his country is ready to enter, partially due to its democratic institutions being regarded as underdeveloped. Hence, a report from the European Commission for 2019 notes that Albania has made major changes but is required to lay emphasis and focus on issues such as corruption and organized crime. Corruption remains prevailing in many areas and remains a concerning issue. Consequently, in a recent interview for Aljazeera, Edi Rama stated that "I think Albania has a problem with organized crime and corruption as every country that is not yet a modern, functioning state. That's why we are in this process, that's why we are not members of the EU, or that's why I am not pretending that it's an injustice that we are not members today. We need to prepare, we need to modernize, and fighting corruption and fighting organized crime is about very strong will, but it's about very strong institutions and very strong mechanisms and functioning in every direction" ("PM Edi Rama: Albania is Europe's bleeding organ", 2019), he stated.

Currently viewing and comprehending the condition and foreign policy of Albania, the statement is obvious. On the other hand, if the country is to be viewed five years ago and where the individuals came from, they have improved significantly. However, once the future is viewed and where the country wants to go, what it aims to achieve, a large amount of action is to be done. Both the EU and Albania will gain benefits following the accession talks in case they are successful.

Quoting Rama and his statement that "Albania and the western Balkans are surrounded by EU borders, so we are somehow an organ of a body that is dragging out of the body but is not simply fading away but it is there. So, the choice is very simple; let this organ bleed and create troubles to the whole body ... or help this organ to integrate and help the body to get the organ in." ("PM Edi Rama: Albania is Europe's bleeding organ", 2019) The significance of this fact lays in the general idea of disasters in the country of Albania ought to have impacts on the region and the EU as well. Followed by the sentence that "It's not about enlargement, it's about completion, it's about a very important piece of the puzzle .... [It is] an area ... within the European Union that should not 
be left as an open space for other actors that may not be very keen to see the European Union progress and prosper". ("PM Edi Rama: Albania is Europe's bleeding organ", 2019) Regardless of that being accurate and making sense, it does not exclude the point of this being only a mere political method of Edi Rama to gain what he aspires to.

Moreover, as elaborated above, the individual and personal characteristics of Pacolli discussed previously may be encountered in a recent statement on his social media profile "Congratulations to European Union and its member states for finding the courage to move ahead with visa facilitation with Belarus and continuing to keep Kosovo the only country in Europe isolated and unable to travel free. I would like to see Ambassador John Rohde and Nataliya Apostolova what do they say now?" (Pacolli, 2020) The relevance of this statement is the persistent focus of Pacolli to foster his country's European integration process. One of the comments regarding this statement is "Well, why we for the sake of people there shouldn't do what we apply in Kosovo since independence in 2008? Visa facilitation is not visa liberalization. Just to clarify what we're talking about" (Rohde, 2020) by the German ambassador to Kosovo.

On the contrary to Albania and its process towards integrating into the EU, "Kosovo is in this stage for ages. The fact that the EU finds the political will to move with Belarus, an autocracy, and keeps in the drawer the EU Commission recommendation to enable free travel for Kosovo is absurd and unfair to the people of Kosovo. The EU can be viewed as treating the Flag of Kosovo with double principles. Yet, despite the conjoined foreign policies of the two countries, Kosovo tends to be in a much more difficult position and tends to have a much longer path ahead towards the EU accession.

On the other hand, it could be argued that the EU has "hidden" aspirations in practice in a sense that the EU "takes it out on" the Western Balkan states including the two countries in the discussion. Despite the commonly known facts of Albania and Kosovo not having the ideal country, institutions, government, or individuals responsible, the behavior of the EU and its relationship to the Western Balkans is an illustrative representation of the region's complicated situation. Formally, the EU is continually expressing its "support" and "concerns" concerning the Western Balkans, while in fact; the EU is moving the region away from participation in the organization with its actions. (Western Balkans, Attempt at repeating history, 2020 )

To make the contradiction even bigger, though EU leaders often extend their assistance to the Western Balkans and its Euro-Atlantic route and raise concerns regarding the presence of certain actors in the region, primarily Russia, China, and Turkey, throughout its (non)enlargement strategy, the EU is simply pushing the Western Balkans into Russia's 'arms,' although at the same time blaming the West. The EU has been viewed to constantly set the Western Balkan countries with new requirements and qualifications for EU membership and integration process. This has been confirmed by scholars warning that 15 EU member states currently do not fully meet the expected membership criteria from the Western Balkan countries. (Ifimes, 2020) These cases include the granting of EU membership to only half of Cyprus, the example of the French province of Corsica, and the Italian province of Sicily where the application of EU regulations is distant from what these standards and regulations actually ought to be. (Ifimes, 2020) What is more, it can be pointed out that the EU has been more "tolerant" with Bulgaria and Romania, as well as with Croatia recently, while collaborating as full-fledged members with them in the EU. 


\section{CONCLUSION}

The primary objective of this research is to provide answers to the research questions of to what degree are the foreign policies of Albania and Kosovo similar and their relations with the EU. As elaborated previously throughout the research one of the general assumptions would be that their foreign policies tend to be very similar and persistent to generally the same goals. Such goals are in the broadest sense oriented towards the EU and Euro Atlantic integrations. However, it may be said that a lack of strategic approach by the EU to the West Balkans is present. Furthermore, such similarities are consequential firstly to the demographic similarities present among the two countries such as the over $80 \%$ Albanian ethnicity as well as the religious majorities. Next are the questions of how similarly or differently do the two states of Albania and Kosovo interact and cope with different international organizations and third states. The answers to such questions may be encountered in the elaborations of actors in the international arena such as the EU.

As of the near future, a possibility of Kosovo unifying its country with Albania is present as well as a possibility of Kosovo starting to be controlled by a movement defending its total independence from Serbia. Albania and Kosovo are considered as "weak" countries, especially Kosovo having an insignificant amount of international power on its own. Consequently, it is difficult to state that such a move when it comes to Kosovo will result in success in establishing new ways of conducting international politics. Kosovo has its stability remain as essential for its citizens, neighboring country of Albania, the region as well as the continent.

Furthermore, this study is estimated to be influential and significant within the scope of its topic because the absence of comparative research regarding Albania and Kosovo is evident. Primarily, this lack infers to the topic and research of the foreign policies of Albania and Kosovo followed by their comparison and their position in regards to significant international organizations such as the EU. Moreover, the results following the research are probable to enrich as well as expand the existing literature primarily by assisting the process of filling the research gap regarding this topic. The major issues within the foreign policies as well as the mutual relations of Albania and Kosovo with significant state and non-state actors in the international arena are of ethnical and historical origin. Consequently, in terms of the above-stated research questions the result and finding that Kosovo has enriched the geopolitics of the Balkans by undertaking an appropriate decision and creating a new state the Republic of Kosovo.

Yet when it comes to Albania and its foreign policy's comparison with that of Kosovo along with their bilateral relations it is significant to point out that Albania is considered one of the major supporters of Kosovo and its actions. By that, the well-established diplomatic bilateral relations and the similarities of their foreign policies have an effect of increasing the recognition of Kosovo's independence as well as improving the position and reputation of Albania in the international relations arena. It is expected that Albania having the foreign policy it currently has will transform into one of the "successful" states of the region in the long run. However, Kosovo will achieve that by facing hardships in terms of its government, foreign policy, and international recognition by states which yet have not recognized it as an independent. When comparing the opportunities and future aspects for Albania and Kosovo it can be stated that Kosovo is in a 
situation with a small population, without its currency, landlocked, and with limited recognition in which to begin with Albania is not. The recognition of Kosovo is the major issue which once solved would lead the citizens of both Kosovo and Serbia to turn the page and solve other aspects such as civil rights and the economy. Both Albania and Kosovo are located in a strategic place within the Balkans and play a key piece in the international relations arena.

Similarly, Albania is an economically, militarily, and politically weak country that has pursued assistance from third actors meanwhile attempting to concentrate on significant matters in the international relations arena. Its geographic location attracts Albanians towards the rest of the continent of Europe. In general, the consistent emphasis of Albanian foreign policy has been focused on the internal economic development and the promotion of external security despite having different political systems since its independence (monarchy, communist, representative government). Furthermore, Albania continues its venture towards becoming a member of the EU as well as strengthening its relations with countries such as Turkey. Another conclusive point would be the recent video summit organized by the Atlantic council from Washington where the US Deputy Assistant Secretary for Western Balkans Mathew Palmer emphasized that "The countries in the Western Balkans understand that their economic future lies in regional cooperation and integration into the European family of nations and a successful economy". (times, 2020) in a sense that Albania and Kosovo are dependent on international and regional cooperation due to their weak internal characteristics.

\section{REFERENCES}

2020 Western Balkans: Attempt at repeating history - Times. Ifimes.org. (2020). Retrieved 8 August 2020, from https://www.ifimes.org/en/9878.

About BehgjetPacolli: Swiss businessman (born: 1951)|Biography, Facts, Career, Wiki, Life. PeoplePill.Retrieved 7 August 2020, from https://peoplepill.com/people/behgjet-pacolli/.

About Ilir Meta: Albanian diplomat and politician (1969-)| Biography, Facts, Career, Wiki, Life. PeoplePill.Retrieved 7 July 2020, from https://peoplepill.com/people/ilir-meta/.

Albania: New Foreign Initiatives (p. 20). (1984).

https://www.cia.gov/library/readingroom/docs/CIA-RDP85S00316R000200090004-7.pdf

Balkan Focus - Just who is BehgjetPacolli?.Balkanfocus.com. (2011). Retrieved 8 September 2020, from http://balkanfocus.com/2011/02/just-who-is-behgjet-pacolli.

Ballina - Ministry of Foreign Affairs - Republic of Kosovo. Mfa-ks.net. Retrieved 7 June 2020, from https://www.mfa-ks.net/.

Brdo-Brijuni Declaration: "EU is able to absorb the WB", Serbia's phrasing of the point on regional borders rejected - European Western Balkans. (2021). Retrieved 30 December 2021, from https://europeanwesternbalkans.com/2021/05/17/brdo-brijuni-declaration-eu-is-able-toabsorb-the-wb-serbias-phrasing-of-the-point-on-regional-borders-rejected/ 
Domi, E. (n.d) Albania's "Balkans Schengen" from an IR perspective. Ibn Haldun University, Istanbul.

Dzananovic, N. (2020). Foreign Policies in Western Balkans. Freidrich Ebert Stiftung. Retrieved 8 September 2020, from.

Europe :: Albania - The World Factbook - Central Intelligence Agency. Cia.gov. (2020).Retrieved 8 August 2020, from https://www.cia.gov/library/publications/the-worldfactbook/geos/al.html.

Europe :: Kosovo - The World Factbook - Central Intelligence Agency. Cia.gov. (2020).Retrieved 10 August 2020, from https://www.cia.gov/library/publications/resources/theworld-factbook/geos/print_kv.html.

European Commission. (2020). COMMISSION STAFF WORKING DOCUMENT Albania 2020 Report Accompanying the Communication from the Commission to the European Parliament, the Council, the European Economic and Social Committee and the Committee of the Regions 2020 Communication on EU Enlargement Policy.

https://www.euronews.com/2020/02/27/albania-president-ilir-meta-my-country-is-becoming-thenorth-korea-of-europe.

Jamieson, A., \&Sandford, A. (2020). My country could be 'North Korea of Europe' againAlbania president. euronews. Retrieved 8 August 2020, from

Kosovo I Albanija potpisali sporazum o ujedinjenju vanjske politike. Al Jazeera Balkans. (2019). Retrieved 8 September 2020, from http://balkans.aljazeera.net/vijesti/kosovo-i-albanija-potpisalisporazum-o-ujedinjenju-vanjske-politike.

Latest developments | Accordance with international law of the unilateral declaration of independence in respect of Kosovo | International Court of Justice. (2021). Retrieved 30 December 2021, from https://www.icj-cij.org/en/case/141

Pacolli, B. (2020). Twitter. Twitter.com. Retrieved 15 September 2020, from https://twitter.com/pacollibehgjet/status/1300263481699172352.

PM Edi Rama: Albania is Europe's bleeding organ. Aljazeera.com. (2019). Retrieved 7 July 2020, from https://www.aljazeera.com/programmes/talktojazeera/2019/06/pm-edi-ramaelections-albania-ready-join-eu-190616083045152.html). 